\title{
Detachment as a Prerequisite for a Happy Family: A Study of Genesis 2:24
}

\author{
Obiorah Mary Jerome \\ Department of Religion and Cultural Studies \\ University of Nigeria, Nsukka, Nigeria \\ obiorah.jerome@unn.edu.ng/mjchukwu@yahoo.co.uk
}

\author{
Doi:10.5901/mjss.2016.v7n4p
}

\begin{abstract}
The narrator of the second account of creation, precisely on God's solicitous plan to find a fitting partner for man, concludes with an insightful observation that serves both as a conclusion and an interpretation: "Therefore a man leaves his father and his mother and clings to his wife, and they become one flesh" (Genesis 2:24). In a strong patrilineal culture in which this text was composed, presenting a man as the one leaving home to join his wife calls for a profound reflection on the message of this Biblical text in a context that appears as an etiology. The point of emphasis seems to rest on the necessity of detachment as a necessary condition in order to create an efficacious bond between the man and "his helper as his partner" (Genesis 2:18). Employing a literary exegetical approach, this paper attempts to explain the sociological and theological implications of Genesis 2:24. Self-effacement interpreted as "leaving father and mother" in Genesis 2:24 prepares a man and a woman for a new life where they are responsibly free to form "one flesh", according to the divine plan.
\end{abstract}

Keywords: aetiology, detachment, family, Genesis 2:24, marriage

\section{Introduction}

Could Genesis 2:24 be a continuation of the poetic exclamation of Adam (the man) ${ }^{1}$ at the sight of his appropriate "helper as his partner"2 'ezer keneḡdô whom he has also given the name "woman" 'iššāh, the meaning of which he explained in the same verse? Conversely, the layout of v.24 shows that even if it were uttered by the man, there is a significant shift in the mood of the two adjacent verses; that is, verses 23 and 24. The initial adverb 'al-kēn translated as "therefore" in v.24 signals a conclusive and explanatory assertion that is a consequence of the previous statement. Furthermore, a careful reading of the immediate context of v.24 has proved it to be an aetiological summary (Von Rad 1996) of the short pericope that begins from v.18.

Actually verses 18-24 focus on God's concern for the man's loneliness: "It is not good that the man should be alone" (v.18a). Loneliness does not have that intrinsic functional goodness which Hebrew expresses with the term țôb "good". In the second part of the same verse, there is a divine proposal: to make man "helper as his partner" 'ezer $k^{e} n e \bar{g} d \hat{o}$. The rest of the story succinctly relays how God successfully achieved this. Verse 24 comes as a conclusion and an explanation. In this discernible conclusion, the verse includes a saying that seems strange in a highly patriarchal milieu in which this story was generated and in a culture that marriage, as it is divinely instituted here, knew no other except patrilocal. A man's leaving of his father and his mother and clinging to his wife was not customary in the Old Testament context. It was usually a woman that would leave her parents' home to join her husband in his. Could the conclusion in v.24 be considered a residue from a time when marriage was matrilocal? Again, does the text intend to communicate a message that is beyond the apparent?

This paper attempts to give an answer to the puzzle and to understand the true significance of this explanatory conclusion. It is believed that the narrator had an intention in making such an unusual statement, and that its emphatic position at the end of an obvious aetiology has a concrete message to convey. Other significant points embedded in this bipartite verse, such as contained in the use of the verb dābaq "cling" and the phrase "to become one" or according to the literal rendition of the original Hebrew "to become one flesh", are carefully analyzed. One would surmise that leaving a paternal home to another place is a significant and symbolic gesture which might not be taken in its face value. It entails most certainly a necessary separation which is required for a new life with another person. Therefore, the main objective

\footnotetext{
1 The original Hebrew version of this has definite article hā'ādām, indicating, perhaps, the universal aspect (humanity) of this word.

2 Unless otherwise indicated, Biblical quotations in English are according to the New Revised Standard Version, Catholic Edition. Nashville: Thomas Nelson, 1993.
} 
of the paper is to elucidate the concept of this fundamental detachment in the context of the untold upheavals that threaten family values in our time. Narrative method of exegesis is employed in the course of this study because the text is presented in the Book of Genesis as a narrative. Discovering the techniques of narration in the text enhances our understanding of its meaning and significance in our world today.

\section{Insight into Genesis 2:24}

\subsection{Contexts of Genesis 2:24}

Tracing and inserting Genesis 2:24 in its context shed more light on its function in the text. The context is the second account of creation which is different from the first creation narrative in Genesis 1:1-2:4a. The two accounts of creation differ in their styles, contents, and theological orientations. The second begins from Genesis 2:4a and its anthropocentrism is almost palpable for everything centers on hā'ādām "the man". He is in this narrative a special beneficiary of the Creator's munificence which increases in intensity until v.24. God makes him participate in his life by giving him breathe of life from God himself. He, hā'ādām, who was made from the dust of the ground, hā'ădămăh, became a living being when God breathed into his nostrils the breath of life, articulated in Hebrew as nišmat hayyîm. The first word, nišmat is from nešāmāh which means "breath", "wind", "breath of life", living creature". If one of the meanings of this word is "breath of life", there is an added emphasis by qualifying it with a word, hayyîm, that also means "life". Actually, hayyîm accentuates it as life-giving breath. It is significant that nišmat hayyîm is from God. "Without nešāmâ, then, the human being is dead and the nešämâ as the characteristic feature of life reveals human beings as bound together inseparably with Yahweh" (Lamberty-Zielinski 1996:66).

Besides nišmat hayyîm from God which made hā'ādām "the man" become a living being nepeš hayyāh, the magnanimous Creator also prepared a well-watered garden for this first human being where he could freely eat from the tree planted therein. This special care for the man reaches its climax in God's plan to secure 'ezer keneḡdô "a helper as his partner". The meaning of this expression which is essential in this divine plan can be deduced from the process the Creator employed in bringing this partner into being. A part of the partner was taken from the man, making them have a substance in common. While other creatures did not have the criteria of "ezer keneḡ dô "a helper as his partner", this new creature, who has something of the man, symbolized as his rib, was able to fulfill the criteria. Someone affirms that it was the woman's intelligence, which was not found in other creatures, that qualified her to be the man's helper and the one who corresponded to the man (Whitekettle 2009). This can be considered as one of those qualities that make her man's partner. One can also add that the woman possesses what the man has such that both of them are able to form one flesh. $^{3}$

The Creator's attentive and tender care for human being and the plan to secure a creature that truly corresponds to him (vv.18-24) is the immediate context of v.24. In point of fact, v.24 concludes as well as explains the divine action narrated in verses 18-24. The passage has been recognized as a narrative on the divine institution of marriage and the beginning of human family. The natural attraction between the two partners is symbolized in using the man's rib in creating the woman. The rib in this text (Gen 2:21) is understood as pars pro toto for the bones, as the most stable constituent of the human body (Brandscheidt 2002). The woman has this stable part of the man and the man is aware that the woman has an essential part of him: "This at last is bone of my bones and flesh of my flesh; this one shall be called Woman, for out of man this one was taken" (Gen 2:23).4 "Man discovers woman as another 'l', sharing the same humanity". ${ }^{5}$ The second part of this poetic exclamation of the man explains the two Hebrew words used for man ('îs) and woman ('iššäh). With the man's recognition of the being and the presence of his partner, v.24 appears a fitting conclusion. A man leaves his natural domain and clings to her who has a part of him.

\subsection{Aetiological Import of Genesis 2:24}

An outstanding literary device or figure in the Bible, particularly in the Book of Genesis is the use of aetiology, causae redditio. It is often explained as a rendering a reason, a showing a cause for something. It is also called apodeixis which

\footnotetext{
${ }^{3}$ This act of forming one flesh will be explained below.

${ }^{4}$ This short poem of the man contains many standard poetic techniques seen in Hebrew poetry: parallelism, assonance, word play, especially with the two Hebrew words for man and woman, chiasmus and verbal repetition For a commentary on this, cf. G.J. Wenham, Genesis 1-15 page 70 (see the Reference).

${ }^{5}$ The Catechism of the Catholic Church, no.371
} 
is a full demonstration of something or to point out the cause of a particular practice or why a name is given to a place or thing (Bullinger 2003). In Genesis, for instance, a short story is narrated to demonstrate the reason for the existence of a given practice or why a place is called by a particular name. The short story ends with enunciation of the reason for the narrative. Genesis 2:24 has been identified as the first in the series of this literary figure (Davidson 1973). The conclusion at the end of aetiological narrative is articulated as a personal comment on the story told.

A read-through of some examples of this literary style in Genesis helps one appreciate the import of Gen 2:24 and the story of which it is more than a mere conclusion. Genesis 11:1-9 tells the story about the Tower of Babel and at the end, verse 9, the meaning of this name, Babel, is given, being derived from the story just narrated. It is called Babel because, according to verse 9, God confused the language of the ambitious and overweening proud builders. Actually, the Hebrew word for "to confuse", bālal, has some assonance with the name Babel. In Genesis 21:22-34, the reason for the name Beersheba is explained with a story. It is a place where Abraham and Abimelect made a covenant (they took an oath). Beersheba literally means "the well of the oath" or the "well of the seven". Similarly, in Genesis 28:10-22, the origin of the name Bethel (house of God) is given. Closely related to this is Gen 33:18-22, El-Elohe-Israel (God, the God of Israel) is given to the altar erected by Jacob at Shechem. Again, Genesis 32:32 concludes a story that begins from verse 22 and gives the reason why the people of Israel do not eat the thigh muscle that is on the hip socket. It is because the person who wrestled with the Patriarch Jacob struck him on the hip socked. In all these examples, the narrators find some incident or explanation for familiar religious or social practice. On the basis of all these texts which have some affinity with Gen 2:18-24, verse 24 may not be considered as a mere gloss randomly inserted by the redactor (Tosato 1990).

In the light of all these examples of aetiology in the book of Genesis, the conclusion in Gen 2:24 can be clearly understood. If Gen 2:24 is the first in the series of this literary device in Genesis, like the others we have seen above, it surely has some specific aim in view. The short narrative it concludes explains a practice. "It was told to answer a quite definite question" (Von Rad 1996). One thinks the question could point to the extremely powerful attraction of the sexes to each other; such drive which the author of the Song of Songs describes with corresponding passion: "for love is strong as death, passion fierce as the grave. Its flashes are flashes of fire, a raging flame. Many waters cannot quench love, neither can flood drown it" (Songs 8:6-7). The author of Genesis 2:18-24, attempting to give a reason for this strong reciprocal attraction of man and woman, sees a clue to this natural human experience in the way God created the woman by using the rib of the man. Being originally one, they must naturally come together. A man leaves his father and mother and clings to his wife in order to effectively achieve this union. It necessitates detachment to arrive at this original state instilled in their existence by the Creator.

Furthermore, it is believed that Genesis 2:24 recapitulates the institution of marriage between one man and one woman. If this is so, then this text does not only attempt to give an answer to the natural attraction between the two human sexes but also to highlight how and why marriage should be: only between one man and one woman. Same-sex marriage and polygamous (Dorey 2004) unions, therefore, are out of place in the divine plan for instituting marriage; this is justified in this verse (Tosato 1990). In line with this is the stability of this union once it is contracted and attained. The two partners have common origin and they tend to be just one flesh. The divine intention for them is to become one; they fulfill the divine design when they remain in this union. Actually, the text subtly accentuates this inseparability of the union of a man and a woman who have joined themselves together to become one; an implicit antidivorce norm reflected in Leviticus 18:18 and Malachi 2:13-16 can be deduced from it (Tosato 1990). In his teaching and argument with his contemporaries (see Matt 19), Jesus employed Gen 2:24 to corroborate his point on indissolubility of marriage.

\subsection{A Close Reading of Genesis 2:24}

There seems to be in Gen 2:24 a consideration that is more than a mere conclusion of aetiology, especially in a closer look at its syntax. The translation in the New Revised Standard Version has "Therefore a man leaves his mother and his father and clings to his wife, and they become one flesh". Following, however, its construction in Hebrew, there is a waw consecutive before the verb "cling". This type of construction, besides converting the verb to conform to the tense of the immediate preceding verb, usually has a secondary idea or purpose which can be translated with "so that", "in order that". It expresses a purpose for the action that comes immediately before it. In this context, the action that comes before it is the verb "leave". The rendition can be stated thus: the man leaves his father and his mother in order to cling to his wife. The next verb continues this purpose clause and hence: in order to become one flesh. Both verbs tend to answer the question: why should a man leave his father and mother? He does so firstly in order to cling to his wife and secondly in order that they may become one flesh. With this clarification, it means that the man cannot cling to his wife unless he leaves father and mother. Again, they cannot become one flesh unless he leaves father and mother and cling to his wife. 
There are then three levels in this leaving, clinging and becoming. Detachment must occur in the first level in order to arrive at the second and consequently at the desired union. What is the essence of these three actions: a. leaving father and mother; b. clinging to wife; c. becoming one flesh?

\subsubsection{A Man leaves Father and Mother}

A major difficulty that one encounters reflecting on this apparent cultural issue is that in a matrilocal system of marriage practiced in the world of the Old Testament, a man usually would not leave home to join his wife. It was the woman that did. There are some who perceive in this text an echo of the custom of having the man become part of his wife's family and household (Plaut 1974). At this stage in our study it does appear that the emphasis of the narrator is not on this cultural issue or familiar custom but on the essence of the aetiology which Gen 2:24 concludes. This essence concentrates on two intertwined considerations; first is the centrality of the man whom the narrative presents as the first to be created; second is the institution of marriage and its divinely designed features which gradually unfold as the narrative progresses.

Beginning with the centrality of hā'āāām "the man", one perceives these points: he was made from the ground; he became a living being by receiving life from the Creator who placed him in a habitable locale with food to sustain him; the Creator sought a worthy partner for him; from a stable part of the man he molded the partner whom the man recognized and accepted; he even gave a name to the woman. Moreover, the narrative in Gen 2:18-24 stresses the need and loneliness of the man; it is natural at this point to talk of the man being united to his wife. Is it not logical that the man remains the centre of attention in the explanatory conclusion in v.24? He is the only active partner in the scene. It is also observed that the woman remains passive throughout, even when the man exclaimed as if in ecstasy before her: "This at last is bone of my bones and flesh of my flesh" (v.23). Therefore, the man's leaving parents to join the wife sustains and continues the tempo of the narrative. The emphasis is not on who leaves, male or female, but on the act of leaving. "The statement in Genesis 2:24 was meant for every human being. Adam had no father and mother; thus it is implied, this is meant for all in the human race; everybody with a father and mother. God was setting up an institution for the human race" (Berkley 2001).

The second consideration focuses on the general essential features of the institution of marriage valid for all cultures. We have discovered above that in the aetiology which v. 24 explicates we perceive the nature of marriage instituted by God. First, it is between a man and a woman; second it must be stable, for just as the partners share one common stable component at the beginning and there is consequently a natural drive to go back to this original, the union that is generated between them sustains this primordial stability. Verse 24 stresses this aspect of marriage when it affirms that a man leaves parents to form one flesh with the wife. "By the leaving of father and mother, which applies to the woman as well as to the man, the conjugal union is shown to be a spiritual oneness, a vital communion of heart as well as of body, in which it finds its consummation" (Keil - Delitzsch).

Therefore, the point of emphasis still rests on the action expressed by the Hebrew verb 'āza $\underline{b}$ with its connotations: to leave, abandon, forsake. In all these there is a relative separation from something or somebody. "A person or a being conceived with personal characteristics removes itself from an object, dissolving thereby its connection with that object" (Gerstenberger 1999:586). This is where its direct object is inanimate. The meaning is basically the same when it involves persons as object. In some cases it can be a violation of the required solidarity; hence it is not lawful to abandon a person to whom one owes this solidarity (Deut 12:19; 14:27; Prov 27:10). Genesis 2:24 belongs to a specialized use of 'āzab whereby in a legal sense it refers to the end of a relationship of solidarity between members of a community or group, with various legal consequences attaching to it. In this text, a man leaves his parents for a legal obligation which is to establish his own household. With this sense, he does not violate his obligation of natural solidarity towards his parents. He has to leave them in order to begin a new life in a new relationship. "As vital and permanent as the child-parent relationship is, a proper husband-wife relationship warrants leaving the earlier relationship" (Berkley 2001).

One believes that the sense of "leaving" in this context is deeper than physical separation from the parents. When a child is still dependent on the parents, he remains submissive to some extent in his will and decision. There is a significant degree of control exercised by the parents over the person with corresponding obligation of the dependant. Separating to form a new relationship severs him from this dependence and at the same time frees him while bestowing on him the required initiative for the new state of life. He needs this freedom because "the bridegroom cannot be both a dependent child and an independent husband in the same home" (Luck 2009). Breaking this natural bond also entails leaving behind a fundamental part of him with the sole purpose of regaining it in a new situation that invigorates his personality and at the same time makes him regain his primordial wholeness. This wholeness is realized in an 
indissoluble union with the "helper as his partner" 'ezer keneḡdô, willed by God for the human race. Furthermore, the detachment empties him in order to enable him be filled in the new relationship. Achieving this new state must make him exclaim: "This at last is bone of my bones ..." (Gen 2:23).

\subsubsection{And clings to his wife}

A man breaks with the past, leaves parents, empties self and becomes receptive in order to be filled anew, according to our understanding of Gen 2:24 above; and this is for a specific purpose which the text articulates thus: "and clings to his wife" or in an explanatory translation "in order to cling to his wife". The sense of this phrase lies in the verb "cling", dābaq in Hebrew. Further meanings of this verb are "to stick to", "to cleave", "join together", and other words that could be synonymous. In Job 41:17 (compare Ezekiel 29:4; $1 \mathrm{Kgs} \mathrm{22:34//2} \mathrm{Chr} \mathrm{18:33),} \mathrm{it} \mathrm{is} \mathrm{used} \mathrm{for} \mathrm{the} \mathrm{scales} \mathrm{of} \mathrm{crocodile} \mathrm{joined}$ one to another such that they cannot be separated without disfiguring the creature. Individual scales of this animal have meaning only when they cleave to one another to form one single whole. Similarly, parts of a graven image fasten to each other to form one mosaic (Isa 41:7). In the context of Gen 2:24, one can say that human beings are complete, like these scales, only when they exist in community. In all these examples, the verb denotes the act of joining together of parts of a whole. Each part cannot exist separately on its own. The relationship between the man and the woman in this text becomes a paradigm for human community and interpersonal intimacy which are characterized by diversity and complimentarity (Wilfong 1988). "The Creator of all made the married state the beginning and foundation of human society; by his grace he has made it too a great mystery in Christ and in the Church" (Vatican II 1965: no.11).

The verb dābaq is also employed figuratively to describe a form of interpersonal relationship (Wallis 1997) that exhibits its general sense. In this figurative sense, particularly its positive aspect, dābaq is parallel to intense love towards a person. In fact, it corresponds to the Hebrew 'ähab "to love", a love that the Song of Songs (8-7) describes thus: "if one offered for love all the wealth of his house it would be utterly scorned". Such was Shechem's passionate desire for Dinah (Gen 34:3). It does not necessarily connote a sexual desire for there are instances where it is used in the Old Testament for same sex relationship. Ruth, for example clings to Naomi, her mother-in-law, because of the love between them. Proverbs 18:24 says of true friendship: "a true friend sticks closer than one's nearest kin".

In Genesis 2:24, dābaq is used figuratively and in a positive sense (Wallis 1997) to portray intense relationship between two persons. It is intense because the persons involved separate themselves from former relationship in order to create something new. "Certainly the idea of cleaving is a whole-hearted commitment to another in an inseparable union" (Luck 2009). Separation from previous intense relationship like the tie between a person and his parents is necessary in order to achieve this inseparable union. In conjunction with this natural tie, all other acquired relationship should be sacrificed for this. The verb dābaq implies passion and permanence (Wenham 1987), and these two are required in marriage.

\subsubsection{And become one}

Clinging to the partner in marriage, according to Gen 2:28, has a precise purpose: the two will become "one flesh" bāśār 'ehẫ. One recalls that in Gen 2:18-24, the woman was created from a significant part of the man, his bone. Initially, both had something in common, bone and flesh (cf.v.23). They cleave to one another to form one flesh, to reflect their original state. In Hebrew, the term bāsaār has been described as "the most comprehensive, most important, and most frequently used anthropological term for the external, fleshy aspect of man's nature" (Bratsiotis 1999: 325). It is the very being and identity of a human person (Vawter 1977). The woman and the man form one identity; this sets their union on the highest and most integral plane: it is a union of persons who together make up a new person (Vawter 1977). We recall that in the man's ecstatic speech, he recognizes that the woman is flesh from his flesh, and bāśär is the word he uses for this exclamation. When they become one flesh, according to v.24, they become what they were originally. In fact, "family is the first form of communion" (Okeke 2008:8).

Becoming one flesh which is a result of leaving and clinging together of the two partners is more than physical union. It also involves union of their personal identities, and having common values. They become one in their being on account of their original common elements: bone and flesh (cf. v.23). Monogamy as a form of marriage in the divine plan cannot have a better Biblical evidence than this; it is a union between one man and one woman. This also should be permanent just as a kin relationship. The two are able to achieve this new union when there is selfless commitment that entails leaving old way of life. Marriage is "permanent commitment to solidarity, fidelity, and fruitful love responds to the deepest longings of the human heart" (Pope Francis 2014). 


\section{Dialectic on Genesis 2:24 and Family}

Who will not be concerned about the degenerating understanding of family values today and unnatural cohabitation in form of marriage? One would think that these values are gradually and steadily disappearing or have already gone into oblivion in some areas because of wrong conceptions about marriage and family. The Church has perceived a danger that is facing human families and is reflecting on how to save the situation. A Preparatory Documents of the Third Extraordinary Synod of Bishops articulates these unusual phenomena which deviate from God's plan for human family in these words:

Concerns which were unheard of until a few years ago have arisen today as a result of different situations, from the widespread practice of cohabitation, which does not lead to marriage, and sometimes even excludes the idea of it, to same-sex unions between persons, who are, not infrequently, permitted to adopt children. The many new situations requiring the Church's attention and pastoral care include: mixed or inter-religious marriages; the single-parent family; polygamy; marriages with the consequent problem of a dowry, sometimes understood as the purchase price of the woman; the caste system; a culture of non-commitment and a presumption that the marriage bond can be temporary; forms of feminism hostile to the Church; migration and the reformulation of the very concept of the family; relativist pluralism in the conception of marriage; the influence of the media on popular culture in its understanding of marriage and family life; underlying trends of thought in legislative proposals which devalue the idea of permanence and faithfulness in the marriage covenant; an increase in the practice of surrogate motherhood (wombs for hire); and new interpretations of what is considered a human right (Synod of Bishops 2013:I).

All these points mentioned above are at variant with the values of marriage and consequently of family as enunciated in Genesis 2:18-24. A man who leaves parents to form a bond as strong as parent-child bond does so according to the divine plan in instituting marriage. It is between a man and a woman and not same sex union. The nature of this new bond shows the coming together of the two partners is the beginning of family. This means that single-parent family contradicts the essence of marriage and consequently of family, and it is unnatural to human race. Increasing number of people and nations of the world who support same-sex marriage generates great concern among many good individuals who still treasure family values. On the basis of the creation of man and woman and the divine institution of marriage between the two genders, marriage between persons of the same sex overtly deviates from the divine plan. It makes man alien to his nature, because the attraction that should be between opposite sex is deformed and diverted.

Again, the frequent divorce that we experience today and which puts many families in disarray, with considerable adverse effect on the children, opposes the durability of marital union presented as a core value in Gen 2:24. Jesus employs the same text in his teaching on the indissolubility of marriage: "So they are no longer two, but one flesh. Therefore what God has joined together, let no one separate" (Matthew 19:6). Marriage is meant to be stable and not temporary. Genesis 2:24 teaches this by using the verb "to cleave" and the phrase "to become one". This oneness is not for some time but until death separates the two. In order to form this durable union, former bond strong as that existing between parents and child has to be dissolved. Divorce arises often when the partners are still tied by different bonds, which do not make them free to form and begin the new union.

All these social ills which threaten marriage and family values are off-shoots of the consequences of overt lack of detachment which is required in order to make a happy family. In a situation where these ills thrive, one observes that the partners are still attached to their old selves and this makes it difficult for them to create a new one.

\section{Conclusion}

In the wake of the growing divergent ideologies on marriage and family values there is need to reflect profoundly on these issues which concern all today. A healthy family is a healthy society, and a happy society depends so much on how families have endeavoured to achieve genuine and lasting happiness. Since marriage and human family have their origin in God, understanding and appreciating their divinely endowed values will certainly help human beings retrace their steps to the divine plan in establishing this oldest human institution.

It is clear that the existing social ills that threaten family values today can be attributed to lack of knowledge of God's design in instituting marriage and family. Human beings have lost sight of what God wanted it to be, and this has its adverse effect on the society. The account of creation as recorded in the first two chapters of Genesis convey this divine plan which human beings have to retrieve in order to save families and the society at large from further harm.

A study of Genesis 2:24, which this paper attempted to do, shows that in order to achieve the required union between a man and a woman in a conjugal relationship, there is need for significant detachment from parental tie and any other that will debar this union from realizing its aim. This is the beginning of the new relationship which is found in 
marriage. A man leaves his father to cling to his wife in order that the two will become one flesh. This rule applies to both the man and the woman, even though the text mentions only "the man". The study has discovered that Gen 2:24 does not refer to any ancient Israelites' matrilocal marriage. Its meaning is embedded in the text, which focuses on God's concern for the loneliness of man. Each of the two partners has to leave behind any bond that will prevent them from establishing firmly their marital relationship.

Besides presenting detachment from parents as a necessary requirement for a successful conjugal union, Gen 2:24 teaches that marriage, according to God's plan, is between one man and one woman; and it has to be durable and not something provisional. Happiness in a family depends so much on correct understanding of God's original plan. This is what the Church does at this time in human history by reflecting on contemporary concepts of family and teaching all to return to God's design.

\section{References}

Berkley, W.E. 2001. "They shall be one flesh" (Genesis 2:24) Expository Files 8.10; www.bible.ca/ef/expository-genesis-2-24.htm; accessed 20 January 2015.

Bratsiotis, N.P. 1999. "flesh", Theological Dictionary of the Old Testament. 3: 317-332. Grand Rapids, Michigan: Eerdmans.

Bullinger, E.W. 2003. Figures of Speech used in the Bible. Grand Rapids, Michigan: Baker Book House.

Brandscheidt, R. 2002. " 'Es ist nicht gut, der mensch allein ist' (Gen 2:18), zur Tradition und Interpretation von Gen 2:18,24; edited by R. Brandscheidt and T. Mende, Schöpfungsplan und Heilsgeschichte: Festschrisft für Ernst Haag zum 70. Geburtstag (Trier: Paulinus Verlag; pp. 29-60.

Davidson, R. 1973. The Cambridge Bible Commentary on the New English Bible: Genesis 1-11. Cambridge: University Press.

Dorey, P.J. 2004. "Genesis 2:24: Locus classicus van monogamie in die Ou Testament? 'n Literêr-historiese ondersoek na perspektiewe op poligame huwelike in die Ou Testament". Old Testament Essays 17:15-29.

Gerstenberger, E. 1999. "abandon", Theological Dictionary of the Old Testament. 10:584-592. Grand Rapids, Michigan: Eerdmans.

Keil, C.F. - Delitzsch, F.J. Commentary on the Old Testament, http://ncbible.info/MoodRes/Moses/Keil\&DelitzschGenesis.pdf; page 80; accessed 23 February, 2015.

Lamberty-Zielinski, H., 1999. "Life-giving breath", Theological Dictionary of the Old Testament. 10:65-70. Grand Rapids, Michigan: Eerdmans,

Luck, W. F. 2009. "Cohesiveness in the Marriage Union - (Genesis 2:24)", https://bible.org/seriespage/1-cohesiveness-marriage-uniongenesis-224; accessed 22 February 2015.

Okeke, V.M. 2008. The Family and Human Life: Pastoral Letter. Enugu: SNAAP.

Plaut, W.G. 1974. The Torah: A Modern Commentary I: Genesis. New York: Union of American Hebrew Congregation.

Pope Francis. 2014. "The Complementarity of Man and Woman in Marriage", when he addressed to members of a Colloquium on this topic at the Vatican; http://en.radiovaticana.va/news/2014/11/17/pope_francis_marriage_and_the_family_are_in_crisis/1111371. Accessed 4 February 2015.

The Catechism of the Catholic Church. 1993. Rome: Libreria Editrice Vaticana.

The New Revised Standard Version 1993. Catholic Edition. Nashville: Thomas Nelson,.

Third Extraordinary Assembly of the Synod of Bishops. 2013. Pastoral Challenges to the Family in the Context of Evangelization: A Preparatory Documents; Vatican City: Libreria Editrice Vaticana.

Tosato, A. 1990. "On Genesis 2:24", Catholic Biblical Quarterly. 52: 389-409. Washington: Catholic University of America, Biblical Association.

Vatican II. 1965. Decree on the Apostolate of Lay People: Apostolicam Actuositatem. Rome: Libreria Editrice Vaticana.

Vawter, B. 1977. On Genesis: A New Reading. London: Geoffrey Chapman.

Von Rad, G. 1996. Genesis. Old Testament Library; London: SCM Press.

Wallis, G. 1997. "to cling", Theological Dictionary of the Old Testament. 3: 79-84. Grand Rapids, Michigan: Eerdmans.

Wenham, G.J. 1987. Genesis 1-15, Word Biblical Commentary 1. Nashville: Thomas Nelson Publishers.

Whitekettle, R. 2009. "Oxen can plow, but woman can ruminate. Animal classification and the helper in Genesis 2:18-24", Scandinavian Journal of the Old Testament 23: 243-256.

Wilfong, M.M. 1988. "Genesis 2:18-24", Interpretation 42:58-63. Richmond: Union Theological Seminary 